\title{
FAMINE FEVERS IN ENGLAND AND IRELAND ${ }^{1}$
}

\author{
By Lieut.-General Sir William MacArthur, K.C.B., M.D., F.R.C.P. \\ - (Reprinted by kind permission, from The fournal of the British Archaeological Association.)
}

After the generalized famine fevers had come to an end in England they continued to scourge Ireland for centuries, where their course may be taken as a repetition of the happenings in England in earlier times. During the eighteenth century and part of the nineteenth, large numbers of the Irish peasantry. lived in a deplorable state of poverty; lacking reserves, one or two bad seasons might suffice to cause a widespread famine. Such national calamities befell, for instance, in the years beginning 1739, I 800, 1816 and 1846. With each famine there came a dreadful epidemic of fever, which broke out with such regularity that its advent was confidently predicted when the famine began. Corrigan, of 'Corrigan's pulse,' popularized the saying ' No famine, no fever'; here 'fever' signified not some scattered cases, or localized outbreaks-these were everyday affairs-but a great and rising tide of pestilence. These epidemics were typhus, with some varying admixture of relapsing fever, the latter disease usually being most in evidence at the beginning and at the

\footnotetext{
1 'Plague' here signifies bubonic plague, primarily a disease of rats, and transmitted to man by fleas. The characteristic inflamed glands show themselves most frequently in the inguinal region, whence 'bubo'(3ov'3), the groin. It affects communities civilized enough to build towns and villages, but not civilized enough to keep them clean. In England in the past it was common knowledge that plague was most likely to break out in warm summers, i.e. a temperature that favours the infection and activity of fleas. Boate, Cromwell's ' Doctor of Physick to the State in Ireland,' wrote: "The plague which so often and so cruelly infecteth England ... is wonderfully rare in Ireland, and hardly seen once in an age - a relative immunity possibly accounted for by the generally lower summer temperature in that country.

Typhus and relapsing fever are conveyed from the sick to the healthy by lice. Both infections propagate most actively in conditions of destitution, squalor, cold, and overcrowding, which favour the breeding and spread of these insects, and epidemics are outstandingly associated with famine. Older names for typhus were jail fever, spotted fever, spotted ague, Irish ague, \&c. Originally 'ague' did not mean malaria, but continued fever, and $\mathrm{w}$ as often applied to typhus, as in Macbeth's ' Till famine and the ague eat them up.'
}

end of the epidemic. In times of scarcity, short of a major famine, extensive epidemics mainly of relapsing fever prevailed at times; but the more general and intense a famine, the more did typhus tend to predominate.

Apart from any lowering of resistance due to hunger, the circumstances of famine produced conditions ideal for the multiplication and spread of lice. The ceaseless rain which often brought about the famine, soaked the footed peat, and in cottage and cabin the fires which customarily burned day and night went out. The occupants had no means of heating water to wash themselves and their clothing, even had they found the heart to try, with death all about them. To keep out the cold they piled on all the rags of clothing they could find, and wore them day and night. They huddled together for warmth, and even those ordinarily cleanly enough became infested with vermin. The rotted potatoes, the nettles and dock leaves eaten raw for lack of firing brought on famine diarrhoea and predisposed to dysentery. Typhus, always smouldering somewhere, flared up and spread. Hoards of starving families deserted their homes and took to the roads in search of food, carrying typhus with them wherever they went. These migrants congregated in the poorer parts of the towns; they swarmed round the charity ' soup-shops' ; they crowded out the hospitals and the jails, for many committed minor offences in the hope of being sent to prison where at least there was food. In such ways there resulted that 'concentration of contagion' which was recognized as productive of typhus at its worst.

The following quotation ${ }^{2}$ shows the horrors of times of pestilence more strikingly than any figures of mortality could do. The letter, signed 'N. M. Cummins, J.P.,' was written from Cork on December 17, 1846-at a date

\footnotetext{
${ }^{2}$ Irish fourn. Med. Sc., Jan. 1938.
} 
when the famine had stil! two vears to run :

To His Grace, Field-Marshall, The Duke of Wellington. My Lord Duke, Without apology or preface, I presume so far to trespass on Your Grace as to state to you, and, by the use of Your illustrious name, to present to the British Public, the following statement of what I have myself seen within the last three days :-Having for many years been intimately connected with the western portion of the County of Cork, and possessing some small property there, I thought it right, personally, to investigate the truth of the several lamentable accounts which had reached me of the appalling state of misery to which that part of the country was reduced. . . . Being aware that I should have to witness scenes of frightful hunger, I provided myself with as much bread as five men could carry, and on reaching the spot I was surprised to find the wretched hamlet deserted. I entered some of the hovels to ascertain the cause, and the scenes that presented themselves were such as no tongue or pen can convey the slightest idea of. In the first, six famished and ghastly skeletons, to all appearance dead, were huddled in a corner on some filthy straw, their sole covering what seemed a ragged horse-cloth and their wretched legs hanging about, naked above the knees. I approached in horror, and found by a low moaning they were alive, they were in feverfour children, a woman, and what had once been a man. It is impossible to go through the details, suffice it to say, that in a few minutes I was surrounded by at least 200 of such phantoms, such frightful spectres as no words can describe. By far the greater number were delirious, either from famine or from fever. Their demoniac yells are still ringing in my ears, and their horrible images are fixed upon my brain. My heart sickens at the recital, but I must go on. In another case . . . my clothes were nearly torn off in my endeavours to escape from the throng of pestilence around, when my neckcloth was seized from behind by a grip which compelled me to turn. I found myself grasped by a woman with an infant, just born, in her arms, and the remains of a filthy sack across her loins-the sole covering of herself and babe. The same morning the police opened a house on the adjoining lands, which was observed shut for many days, and two frozen corpses were found lying upon the mud floor half-devoured by the rats. A mother, herself in fever, was seen the same day to drag out the corpse of her child, a girl about twelve, perfectly naked, and leave it half covered with stones. In another house ... the dispensary doctor found seven wretches lying, unable to move, under the same cloak-one had been dead many hours, but the others were unable to move either themselves or the corpse. To what purpose should I multiply such cases? If these be not sufficient, neither would they hear who have the power to send relief and do not, even "though one came from the dead ...

The terror that these visitations of typhus left behind can be realized from an incident that happened when I was staying in western Ireland as a boy. The peasantry of the district were poor, but there was nothing in the way of destitution, and there had been no typhus locally for a generation. None the less, when the arrival of a lady convalescing from rheumatic fever was expected, my host warned me that her malady must be spoken of as "rheumatism,' for the mere mention of the word ' fever,' however qualified or explained, would cause a panic and lead to a boycott of the house and all its inhabitants.

The point that I wish to make is that if the detailed descriptions of these later famine fevers in Ireland were taken and compressed to the space of half a page, the resulting account would be identical with, say, William of Newburgh's story of the great English famine fever of I 196. Crying out that the hand of God was lifted against the people of Christendom, the chronicler goes on to relate that the bodies of those dead of hunger corrupted the air, thereby causing a raging pestilence which did not spare even the rich, and for the destitute cut short the long torment of hunger. The fever 'that is called the ague ' crept about, seizing so many in the course of a day that those left could hardly minister to the sick, or bury the dead ; and so forth. And if these Irish records were reduced still further to the limit of a few lines we should then have a replica of the brief accounts of famine fever given in the AngloSaxon chronicles. ${ }^{3}$ It is my belief that the widespread epidemics of fever in early England, which were definitely part of a widespread famine, were of the same nature as the later famine fevers in Ireland.

The Yellow Pestilence, Pestis Flava, or Buidhe Chonaill. This great mortality is most widely known under the name employed by the Irish annalists, the Buidhe Chonaill. ${ }^{4}$ It is

\footnotetext{
${ }^{3}$ Zinsser, Rats, Iice and History, 278, objected to my translation of drif, Anslo-Saxon Chronicle, A.D. I087. by 'fever,' and alleged it meant 'diarrhsea,' here copying Ingram's mistake, unfortunately disseminated in a popular translation of the Chronicle. The Rushworth Codex-a Latin MS. of the Gospels with a word-for-word AS. translation interlineated-makes the meaning clear. One example: Matt. viii. 15, 'et dimisit eam febris' is translated, 'and forlet hiae sio drif.' This is final.

${ }^{4}$ Buidhe, pronounced 'bwee ', is the common word for yellow. The second element is pronounced much as written; the chroniclers treat this archaic word as the equivalent of pestis and mortalitas.
} 
often identified with bubonic plague, a view I formerly accepted, though with occasional misgivings. Being familiar with the disease, the question recurred to my mind, "Why should plague be called yellow ?' To meet this difficulty I wondered for a time if 'Buidhe' here might have been used in an intensive sense without reference to colour, 'like 'Black' in 'The Black Death,' for the word has this usage in spoken Gaelic. This far-fetched conjecture, however, was ruled out by the facts that the annalists equated Buidhe Chonaill with Crón Chonaill (crón meaning saffron-coloured), and latinized both names, Pestis Ictericia; and the same pestilence was called in Britain the Pestis Flava. Consequently, 'yellow' must be accepted in the literal sense of colour, and as indicating some epidemic disease with jaundice as an outstanding symptom.

In this connection there are three great pestilences to consider: (I) the Plague of Justinian; (2) the mysterious Buidhe Chonaill : (3) the epidemic recorded by Bede. (I) This pandemic which began about A.D. 543 was bubonic plague, as is clear from Gibbon's account, without going farther afield. In Ireland the disease was called Blefed, not Buidhe Chonaill, and is recorded there as having swept away the noblest third of the human race. (2) The Buidhe Chonaill followed close on Justinian's plague, the date given in the annals varying by a few years in the neighbourhood of A.D. 550, which suggests that there may have been more than one visitation. Of all the great epidemic diseases, plague is by far the most easily recognized because of the characteristic buboes and the great pain often caused by these swellings. If this pestilence had been of the same nature as Justinian's plague which preceded it by only a very few years, no one then alive could have failed to be aware of the fact. It is strange, therefore, that a new name should be introduced, and a name that, applied to plague, seems meaningless. I believe that the chroniclers made use of a different name because they were recording a different disease. (3) Bede's plague, which began in A.D. $664,{ }^{5}$ was bubonic in nature, as is shown by a passage in the Life of St. Cuthbert which

\footnotetext{
; In Ireland, recorded as breaking out in August, 664, a summer 'of extreme heat.'
}

implies that swellings in the thigh (inguinal buboes) were a usual symptom of the infection. Some of the Irish chronicles employ the name Buidhe Chonaill for this epidemic also, a label that has been responsible for much confusion and misunderstanding, for it has been assumed that since this outbreak, known to have been plague, was given this name, then the original Buidhe Chonaill of a century before was plague too.

It is essential to remember that the historical records of those early times exist only as late copies or recensions of the original manuscripts. Where several copies of the same chronicle have survived, ${ }^{6}$ the note, 'to wit, the Buidhe Chonaill,' referring to the plague of 664 , has been added as a gloss in one copy, but not in the others. This shows that the name did not appear in the original text from which the'several copies were derived. There is no doubt in my mind that the association of the name Buidhe Chonaill with the plague of 664 began as a gloss long after the event, made on the mistaken assumption that the pestilence had been of the same nature as that recorded in the preceding century*. If it had in fact been as to merit the descriptive name of the Buidhe Chonaill in Ireland, presumably the name Pestis Flava would once more have been attached to its manifestations in Britain. This is not so.

The error would be a trivial offence in comparison with some of the enormities to be laid to the charge of transcribers. The 'Iteper Hospitals of Armagh '--the ecclesiastical capital of Ireland-are renowned because they are supposed to antedate by several centuries all similar foundations in Europe. I have shown elsewhere? that the 'Leper Hospitals of Armagh' are fantasies of the imagination, and never existed in fact. The whole story is built up on two mistakes. In one, an archaic Gaelic word meaning 'oratories' was translated into late Latin as 'hospitals.' A translator into English then proceeded to paint this

* Since this was written, an examination of the earliest MSS shows that the gloss ' Buidhe Chonaill' for the plague of 664 did not appear until some date after the end of the I I th century, thus confirming the opinion given above.

${ }^{6}$ e.g., Ann. Vlst. The name is interpolated in Chron. Scot., I suggest by Mac Firbis, as his transcript of the Mac Egan MSS. has the same addition.

' Fourn. R.A.M.C., xlv. 6. 
lily, and ,the 'hospitals' of the Latin text became ' leper hospitals' in the English translation. And that is the beginning and the end of the famed-and fabulous-'. Leper Hospitals of Armagh.'

What could the Yellow Pestilence have been ? Clearly it was some contagious malady capable of giving rise to a 'great mortality' extensive enough to have involved both Britain and Ireland, with jaundice as a common and striking feature. Within my knowledge there is only one infection that could possibly fulfil all these requirements, and its identity with the Yellow Pestilence, so far as I am concerned, was first suggested by an old man in Co. Donegal a few years ago. As a child, I heard many tales of 'The Famine' (1846-8), during which my grandfather, like so many doctors, after performing prodigies of devotion, caught typhus himself. Later, and especially when as a student of medicine I had seen typhus demonstrated, I spent many nights listening to stories told by aged survivors of the famine and fever, more vivid and instructive than anything to be read in printed books. Knowing nothing at that time of the ancient Buidhe Chonaill, doubtless I missed many pointers to its identity. The man I mention could not remember the famine, but he had been brought up in a world dominated by memories of that terrible time, and his knowledge, which I could check at many points, was wide and accurate. In conversation one day he said that I had asked much about the spotted fever in the famine, but along with this there was another disease which he had heard his parents and other old people talk of many times, and that was the Fiabhras Buidhe, the Yellow Fever. It was given this name, he explained, 'because those who caught it were coloured yellow with the jaundice.' A light broke in on my mind and I exclaimed, "The Buidhe Chonaill-relapsing fever !'

Jaundice as a complication may occur in relapsing fever, especially in attacks of a severe type. In some outbreaks it is rare, in others common. As different varieties of the causal organism are found in different countries, it is wise to restrict oneself to what is known to have actually happened in the British Isles. In I843, a year of scarcity in Scotland, relapsing fever ' of great severity' prevailed all over the country, including the Hebrides, and in most areas the disease was not obscured by associiated typhus. Jaundice occurred so commonly that when this 'new disease' broke out in Glasgow, where about $I$ in 8 of the inhabitants was attacked, it was popularly supposed to be tropical yellow fever imported from the West Indies, regardless of the fact that it had first appeared in country districts of East Fife. Anderson, of Glasgow, wrote an excellent description of relapsing fever, ${ }^{8}$ which was based solely on his experience of this one epidemic, fortunately for my purpose. Because of the frequency of jaundice, he classified the disease as he saw it, in his group of 'Billious Fevers,' bracketing it with tropical yellow fever, though he recognized that the two diseases are distinct. Graves, of ' Graves' Disease,' declared that his (mistaken) opinion ' as to the identity of the cases of yellow fever occurring in the Irish epidemic of $1826-27$, with the yellow fever of warmer climates' was ' singularly and remarkably proved' by this Scottish epidemic, ' in which cases of yellow fever were very frequent.' Other medical authors wrote to the same effect.

Anderson, in the account mentioned above, gives as 'the characteristic symptom' in 'serious cases' : 'Hepatic fullness and tenderness, evidencing more or less congestion of the liver ; general jaundice, often very deep.'

I consider it beyond all reasonable doubt that the 'mortalitas magna' of the sixth century, named at the time the Pestis Flava and the Buidhe Chonaill, was a severe form of relapsing fever, with jaundice common enough to dominate the general picture of the disease.

8 Ten Lectures introductory to the Study of Fever. 